\title{
Clinical value of selected markers of angiogenesis, inflammation, insulin resistance and obesity in type 1 endometrial cancer
}

Katarzyna M. Terlikowska ${ }^{1 \dagger}$, Bozena Dobrzycka ${ }^{2 \dagger}$, Robert Terlikowski ${ }^{3}$, Anna Sienkiewicz ${ }^{2}$, Maciej Kinalski ${ }^{4}$ and Slawomir J. Terlikowski ${ }^{*}$ (D)

\begin{abstract}
Background: It is a well-known fact show that the risk of developing endometrial cancer (type $1 \mathrm{EC}$ ) is strongly associated with obesity. In this study, selected markers, such as obesity, insulin resistance, angiogenesis and inflammation markers related to EC type 1 progression and patients' survival data were analyzed.

Methods: To measure levels of adiponectin, C-reactive protein (CRP), vascular endothelial growth factor-A (VEGF-A), angiopoietin-2 (Ang-2), insulin-like growth factor-1 (IGF-1), insulin and C-peptide in 176 preoperative serum samples, the immunoassay technique (EMIT) has been applied.

Results: Angiopoietin-2 levels increase with age $(P=0.005)$, FIGO stage $(p=0.042)$, myometrial invasion $(P=0.009)$ and LVSI $(P<0.001)$. The CRP levels increase with age $(P=0.01)$, as well as the advancement of the FIGO stage $(P<$ $0.001)$, higher tumor grade $(P=0.012)$, and myometrial invasion $(P<0.001)$. A positive correlation between serum Ang-2 and CRP levels was demonstrated $(r=0.44 ; p<0.001)$. Kaplan-Meier survival analysis showed that patients with high CRP levels in serum and Ang-2 presented a worse outcome ( $P=0.03$ and $P=0.015$, respectively). Cox regression analysis of individual predictors revealed that high serum levels of Ang-2, CRP, advanced clinical FIGO stage $(P<0.001$, respectively), old age $(P=0.013)$ were all significant overall survival predictors. By means of multivariate analysis, their predictive significance was confirmed.
\end{abstract}

Conclusion: Our study provides evidence that serum levels of Ang-2 and CRP may serve as predictors for assessment of the clinical stage of type $1 \mathrm{EC}$ and are significantly associated with poor prognosis. It is likely that angiogenesis and inflammation associated with obesity have a significant impact on EC type 1 progression and survival rate of patients.

Keywords: Obesity, Insulin resistance, Angiogenesis, Inflammation, Endometrial cancer

\footnotetext{
* Correspondence: sterlikowski@gmail.com

${ }^{\dagger}$ Katarzyna M. Terlikowska and Bozena Dobrzycka contributed equally to this work.

${ }^{5}$ Department of Obstetrics, Gynaecology and Maternity Care, Medical University of Bialystok, Szpitalna 37 Street, 15-295 Bialystok, Poland Full list of author information is available at the end of the article
}

(c) The Author(s). 2020 Open Access This article is licensed under a Creative Commons Attribution 4.0 International License, which permits use, sharing, adaptation, distribution and reproduction in any medium or format, as long as you give appropriate credit to the original author(s) and the source, provide a link to the Creative Commons licence, and indicate if changes were made. The images or other third party material in this article are included in the article's Creative Commons licence, unless indicated otherwise in a credit line to the material. If material is not included in the article's Creative Commons licence and your intended use is not permitted by statutory regulation or exceeds the permitted use, you will need to obtain permission directly from the copyright holder. To view a copy of this licence, visit http://creativecommons.org/licenses/by/4.0/. The Creative Commons Public Domain Dedication waiver (http://creativecommons.org/publicdomain/zero/1.0/) applies to the data made available in this article, unless otherwise stated in a credit line to the data. 


\section{Background}

Endometrial cancer (EC) is one of the most common gynecological malignancy. According to 2018 Global cancer statistics 382,069 women have been diagnosed with endometrial cancer worldwide [1]. In Poland, the age-adjusted incidence rate was 16,61 per 100,000 women in 2018 with 6243 new incidents and 1690 deaths [2].

The dualistic model for EC divides this malignancy into two main categories: type 1 estrogen-dependent endometrioid carcinoma (G1 and G2) and type 2 nonendometrioid carcinoma (G3). Type 1 tumors account for about $80-85 \%$ of all endometrial malignancies and are most often linked to a good clinical outcome. Not only the FIGO stage but also tumor grade, depth of myometrial invasion, LVSI and lymph node status are the most valuable clinicopathological prognostic variables [3, 4].

Obesity is correlated with a chronic, low-grade inflammation which is characterized by raised systemic levels of inflammatory markers which also correlate obesity with the risk of EC [5-9]. Increased adipose tissue mass may be contributing to the development of cancer by elevated production of pro-inflammatory cytokines and chemokines. Several studies confirmed that CRP may influence the secretion of inflammatory cytokines, thus increase the risk of EC [9-11]. Immune cells that secrete the proinflammatory cytokines, such as tumor necrosis factor $\alpha$ (TNF- $\alpha$ ) and interleukin-6 (IL-6) can infiltrate adipose tissue. IL-6 triggers the production of CRP in the liver - this acute phase protein is well-known for its proinflammatory properties [11]. Circulating adipokines, like adiponectin, have a systemic immunomodulatory effect, also play an important role in the development of selected types of cancer. Prospective studies have shown that insulin, IGFBP2, leptin, adiponectin, and $\mathrm{C}$-peptide play an important role in the development of EC [12]. Most cancer-related epidemiological studies have revealed that the risk for type 1 EC development is strongly correlated with obesity. Such correlations have been noticed in both pre- and postmenopausal women as well as in cohort and casecontrolled trials. Postmenopausal obesity refers to increased circulating estrogens which are attributable to the aromatization of androgens in adipose tissue [13]. Obesity is found to be associated with lower levels of sex hormone-binding globulin (SHBG), which leads both, to higher bioavailable levels of estrogen and higher insulin levels. That, in consequence, may increase the risk of EC development [9]. The association of EC and diabetes have been shown in three meta-analyses [14-16]. Several factors including insulin resistance, higher leptin levels, lower adiponectin levels, and chronic inflammation are considered to be important factors in obesity-related carcinogenesis.

Neoangiogenesis sustains the growth, advancement, and metastasis of solid tumors. Vascular endothelial growth factor (VEGF) and angiopoietin 2 (Ang-2) are important regulators of neoangiogenesis in the endometrium [17]. Angiopoietin-2, Tie2 ligand-receptor, and VEGF-mediated pathway are found to be crucial for the regulation of vascular maturation or stability, having been implicated in the control of physiological angiogenesis $[18,19]$.

When the primary tumor volume grows, intratumoral hypoxia increases Ang-2 expression to promote angiogenesis for tumor metastasis. Hypoxic cancer cells mediate functional interactions that promote angiogenesis, lymphangiogenesis, and metastasis [20]. In lung cancer patients it was shown that higher serum levels of Ang-2 were associated with a significantly poorer prognosis. Thus, Ang-2 and Ang-2 mRNA in tissue or sera are thought to be useful diagnostic biomarkers $[19,21]$.

In the present study, we examined a correlation of several markers related to obesity, insulin resistance, neoangiogenesis and inflammation with type 1 EC development and patients' survival.

\section{Methods \\ Patients}

The current study was conducted on a cohort of 176 Caucasian women suffering from type $1 \mathrm{EC}$, treated in the Gynecology and Obstetrics Department of the Independent Public Healthcare Facility Regional Complex Jan Sniadecki Hospital in Bialystok, Poland in 20062012. The study protocol was approved by the Bioethics Committee at the Medical University of Bialystok, Poland (R-I-003/177/2004). Enrolled patients were informed of the study's purpose and gave their consent for the study. All patients were treated surgically in accordance with FIGO criteria. The standard blood tests, chest radiographs, and abdominal ultrasound tests including pelvis were performed. In several cases, CT or MRI was performed too. Performed procedures included a hysterectomy with bilateral salpingo-oophorectomy $(n=83)$, hysterectomy with bilateral salpingo-oophorectomy, and bilateral pelvic/paraaortic lymphadenectomy $(n=93)$. Patients included in this study had not been given any preoperative treatment.

Histopathological examination was performed according to the WHO guidelines and classification. To confirm the clinical FIGO stage, the depth of myometrial invasion, histopathological tumor type and grade, and the absence or presence of LVSI and prepare for light microscopy examination, all representative tissue samples were H\&E stained. To avoid any misinterpretations, 
the surgical specimens were presented to two gynecologic pathologists for an independent review.

\section{Collection and storage of samples}

Blood samples were collected into a serum separator tube (Vacutainer, Becton-Dickinson, USA) and allowed blood to clot at room temperature for $30 \mathrm{~min}$. All samples were centrifuged at $3000 \mathrm{~g}$ for $10 \mathrm{~min}$ then collected; the supernatant was stored at $-80^{\circ} \mathrm{C}$ until examination.

\section{Immunoassays}

We used commercially available Quantikine human ELISA kits (R\&D systems, Minneapolis, MN, USA) for adiponectin, high sensitivity-C-reactive protein (CRP), VEGF-A, Ang-2 and IGF-1 and human ELISA kit (Millipore, Billerica, MA, USA) for insulin and C-peptide to measure protein levels in the patients' serum samples. All ELISAs were carried out according to manufacturers' instructions and samples were assayed in duplicate according to proper control standards. Human Total Adiponectin/Acrp30 Quantikine ELISA Kit DRP300 (sensitivity: $0.891 \mathrm{ng} / \mathrm{ml}$, assay range: $3.9-250 \mathrm{ng} / \mathrm{ml}$ ) Human C-Reactive Protein/CRP Quantikine ELISA Kit DCRP00 (sensitivity: $0.022 \mathrm{ng} / \mathrm{ml}$, assay range: $0.8-50$ ng/ml Human VEGF Quantikine ELISA Kit DVE00 (sensitivity: $9 \mathrm{pg} / \mathrm{ml}$, assay range: $31.3-2000 \mathrm{pg} / \mathrm{ml}$ ) Human Angiopoietin-2 Quantikine ELISA Kit DANG20 (sensitivity: $21.3 \mathrm{pg} / \mathrm{ml}$, assay range: $46.9-3000 \mathrm{pg} / \mathrm{ml}$ ) Human IGF-I Quantikine ELISA Kit DG100 (sensitivity: 0.056 $\mathrm{ng} / \mathrm{ml}$, assay range: $0.1-6 \mathrm{ng} / \mathrm{mL}$ Human Insulin ELISA EZHI-14 K Millipore (sensitivity: the lowest level of insulin that can be detected by this assay is $0.85 \mu \mathrm{U} / \mathrm{mL}$ when using a $20 \mu \mathrm{l}$ sample size, specificity: $100 \%)$. Human C-Peptide ELISA EZHCP-20 K Millipore (sensitivity: the lowest level of Human C-Peptide that can be detected by this assay is $0.05 \mathrm{ng} / \mathrm{ml}$, specificity: $100 \%$ ). Personnel running the assays was not informed of patients' clinical status, and the results were disclosed to the surgeons only after recording patients' disease status. The test precision for markers was performed in accordance with the protocol guidelines of the Clinical and Laboratory Standards Institute (CLSI) [22].

\section{Data collection}

Demographic and clinical data, as well as the pathology report for every patient, have been prospectively stored in the hospital database. Baseline height, weight, and BMI have been acquired from medical records along with the follow-up information. The BMI was established in consideration of the World Health Organization classification: $<18,5 \mathrm{~kg} / \mathrm{m}^{2}$ - underweight; $18,5-24.9 \mathrm{~kg} / \mathrm{m}^{2}$ - normal; $25-29.9 \mathrm{~kg} / \mathrm{m}^{2}$ - overweight; $\geq 30 \mathrm{~kg} / \mathrm{m}^{2}$ - obese [23]. The BMI decreased with age >
60 years. Only $1.1 \%$ of patients appeared to be underweight, $8.5 \%$ were normal, $52.3 \%$ - overweight and $38.1 \%$ were obese, among them $5.4 \%$ morbidly obese. Twentyone patients (11.9\%) were diagnosed with diabetes mellitus type 2 . All follow-ups were concluded before $30 \mathrm{Sep}-$ tember 2018.

\section{Statistical analysis}

Statistical analysis was performed in Statistica software package 13.3 PL (StatSoft, Inc. StatSoft Poland Ltd.). Frequency and descriptive statistics were applied to characterize the cohort. Independent-sample T-tests to compare serum markers levels in patients with or without LVSI, myometrial invasion, FIGO stage, grade, and age were used (or Mann-Whitney-U test when appropriate). Correlation between the selected markers of angiogenesis, inflammation, insulin resistance and obesity was assessed using Pearson's correlation analysis. Biomarkers that showed significant correlation were analyzed by linear regression to determine the working relationships between the biomarkers. We successively conducted both Kaplan-Meier and Cox regression analyses so that we could analyze the overall survival of the patient. We applied medians in order to divide continuous data into groups for Kaplan-Meier analysis, with standard cut off points for BMI. For the continuous variables, hazard ratios were estimated using the following units: 100 units of VEGF-A, 1000 units of Ang-2, 1 unit of CRP, insulin, C-peptide, and BMI, 10 units of IGF-1 and per decade of age. Predictors were entered either on their own or jointly; stepwise procedures were not used. The Coxproportional hazard model was used to assess the prognostic value of serums VEGF-A, Ang-2, Adiponectin, Insulin, C-peptide, CRP, IGF-1 and BMI as logtransformed continuous factors in univariate and Ang-2 and CRP in multivariate analyses. The base model consisted of traditional prognostic factors such as FIGO stage, age, tumor grade, myometrial invasion, and LVSI. Levels of VEGF-A, Ang-2, Adiponectin, Insulin, Cpeptide, CRP, IGF-1 and BMI were entered separately in a second block. Points estimated were reported as hazard ratios (HRs) and 95\% confidence intervals (CIs). $P<$ 0.05 was found to be statistically significant.

\section{Results}

The trial cohort consisted of 176 patients with type 1 EC. The clinical characteristics of study participants are summarised in Table 1. Patients ranged in age from 54 to 87 years (median $=69)$ with $67.6 \%$ of patients $\leq 60$ and $32.4 \%>60$ years of age. All tumors were clinically, surgically and histopathologically categorized as follows: 131 patients $(74.4 \%)$ were FIGO first stage, $23(13.1 \%)$ - second stage, $18(10.2 \%)$ - third stage and $4(2.3 \%)$ - fourth stage (= stage IVA only). Lymphatic vascular space 
Table 1 Patients characteristics

\begin{tabular}{lll}
\hline & $\mathbf{N}$ & $\mathbf{( \% )}$ \\
\hline Total & 176 & $(100)$ \\
Age (years) & & \\
$\leq 60$ & 119 & $(67.6)$ \\
$>60$ & 57 & $(32.4)$ \\
FIGO stage & & \\
I & 131 & $(74.4)$ \\
IA & 79 & $(44.9)$ \\
IB & 52 & $(29.5)$ \\
II & 23 & $(13.1)$ \\
III & 18 & $(10.2)$ \\
IV & 4 & $(2.3)$ \\
Lymphatic vascular space invasion & \\
Yes & 62 & $(35.2)$ \\
No & 114 & $(64.8)$ \\
Myometrial invasion & & \\
$<50 \%$ & 79 & $(44.9)$ \\
$\geq 50 \%$ & 97 & \\
Histological grade & & \\
G1 & & \\
G2 & 105 & $(59.1)$ \\
\hline
\end{tabular}

invasion (LVSI) was identified in 62 patients (35.2\%). Myometrial invasion $\geq 50 \%$ was recorded in 97 (55.1\%) out of 176 tumors. All samples were categorized according to their histological grade: $105(59.7 \%)$ were found to be grade 1 and 71 (40.3\%) were grade 2 .

Serum levels of the angiogenic factors VEGF-A and Ang-2 and the inflammatory factor CRP, with reference to clinicopathological features are displayed in Table 2. The VEGF-A levels were considerably elevated when LVSI and myometrial invasion $(\geq 50 \%)$ was present $(P=0.013$ and $P=0.002$; respectively). Angiopoietin-2 levels increased with age $(P=0.005)$, myometrial invasion $(P=0.009)$, LVSI $(P<0.001)$ and FIGO stage $(P=0.042)$. The CRP levels increased with age $(P=0.01)$, FIGO stage $(P<0.001)$ and higher grade $(P=0.012)$, and also with myometrial invasion $(P<0.001)$.

Data for metabolic factors such as adiponectin, IGF-1, insulin, $C$-peptide and BMI values are presented in Table 3. Adiponectin levels increased with age $(P=0.001)$. There were no statistical differences found in the levels of IGF-1, insulin, C-peptide according to clinicopathological features.

Pearson's correlation analysis was performed to determine whether there were correlations between angiogenic, inflammation and obesity-related factors in type 1 endometrial cancer patients. There was a significant negative correlation between adiponectin and IGF-1, insulin, Cpeptide and BMI $(r=-0.19 ; p<0.001, r=-017 ; p=0.003$, $r=-0.16 ; p=0.02$ and $r=-0.31 ; p<0.001$, respectively). A significant negative correlation was observed between CRP levels and IGF-1 $(r=-0.17 ; p<0.001)$. The measured

Table 2 Serum angiogenic and inflammatory factors according to clinicopathological features in type 1 endometrial cancer patients

\begin{tabular}{|c|c|c|c|c|c|c|c|}
\hline & $\mathrm{N}(\%)$ & $\begin{array}{l}\text { VEGF-A }(\mathrm{pg} / \mathrm{ml}) \\
\text { Mean }( \pm \mathrm{SD})\end{array}$ & $P$-value & $\begin{array}{l}\text { Ang-2 }(\mathrm{pg} / \mathrm{ml}) \\
\text { Mean }( \pm \mathrm{SD})\end{array}$ & $P$-value & $\begin{array}{l}\text { CRP }(\mu \mathrm{g} / \mathrm{ml}) \\
\text { Mean }( \pm \mathrm{SD})\end{array}$ & $P$-value \\
\hline Total & $176(100)$ & & & & & & \\
\hline \multicolumn{8}{|c|}{ Age (years) } \\
\hline$\leq 60$ & $119(67.6)$ & $414(398)$ & 0.632 & $2012(891)$ & 0.005 & $3.61(2.68)$ & 0.01 \\
\hline$>60$ & $57(32.4)$ & $391(370)$ & & $2948(1246)$ & & $4.98(3.29)$ & \\
\hline \multicolumn{8}{|c|}{ FIGO stage } \\
\hline$|-| \mid$ & $154(87.5)$ & $347(221)$ & 0.061 & $2212(1372)$ & 0.042 & $3.46(2.97)$ & $<0.001$ \\
\hline III-IV & $22(12.5)$ & $432(443)$ & & $2968(1314)$ & & $6.92(3.17)$ & \\
\hline \multicolumn{8}{|c|}{ Lymphatic vascular space invasion } \\
\hline Yes & $62(35.2)$ & $453(312)$ & 0.013 & $3102(1652)$ & $<0.001$ & $5.11(3.09)$ & 0.114 \\
\hline No & $114(64.8)$ & $349(305)$ & & $2451(1232)$ & & $4.32(3.39)$ & \\
\hline \multicolumn{8}{|c|}{ Myometrial invasion } \\
\hline$<50 \%$ & $79(44.9)$ & $316(181)$ & 0.002 & $2183(1386)$ & 0.009 & $3.09(2.97)$ & $<0.001$ \\
\hline$\geq 50 \%$ & $97(55.1)$ & $411(371)$ & & $2953(1216)$ & & $5.11(3.28)$ & \\
\hline \multicolumn{8}{|c|}{ Histological grade } \\
\hline G1 & $105(59.7)$ & $392(402)$ & 0.125 & $2562(985)$ & 0.135 & $2.54(1.98)$ & 0.012 \\
\hline G2 & $71(40.3)$ & 375 (328) & & $2746(1134)$ & & $4.16(2.97)$ & \\
\hline
\end{tabular}


Table 3 Obesity-related factors according to clinicopathological features in type 1 endometrial cancers patients

\begin{tabular}{|c|c|c|c|c|c|c|c|c|c|c|c|}
\hline \multirow[t]{2}{*}{ 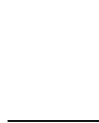 } & \multirow[t]{2}{*}{ N (\%) } & Adiponectin (ng/ml) & \multirow[t]{2}{*}{$P$-value } & \multirow{2}{*}{$\begin{array}{l}\text { IGF-1 (ng/ml) } \\
\text { Mean ( }( \pm S D)\end{array}$} & \multirow[t]{2}{*}{$P$-value } & \multirow{2}{*}{$\begin{array}{l}\text { Insulin }(\mu \mathrm{U} / \mathrm{ml}) \\
\text { Mean }( \pm \mathrm{SD})\end{array}$} & \multirow[t]{2}{*}{$P$-value } & $\begin{array}{l}\text { C-peptide } \\
\text { (ng/ml) }\end{array}$ & \multirow[t]{2}{*}{$P$-value } & BMI & \multirow[t]{2}{*}{$P$-value } \\
\hline & & Mean $( \pm S D)$ & & & & & & Mean $( \pm S D)$ & & Mean $( \pm S D)$ & \\
\hline Total & $\begin{array}{l}176 \\
(100)\end{array}$ & & & & & & & & & & \\
\hline \multicolumn{12}{|c|}{ Age (years) } \\
\hline $\begin{array}{l}\leq \\
60\end{array}$ & $\begin{array}{l}119 \\
(67.6)\end{array}$ & $6791(4132)$ & 0.001 & $98.41(26.84)$ & 0.082 & $18.43(22.59)$ & 0.132 & $4.19(3.45)$ & 0.392 & $29.42(4.21)$ & 0.001 \\
\hline $\begin{array}{l}> \\
60\end{array}$ & $\begin{array}{l}57 \\
(32.4)\end{array}$ & $8154(5321)$ & & $95.35(29.87)$ & & $14.98(24.78)$ & & $4.93(3.74)$ & & $27.14(5.16)$ & \\
\hline \multicolumn{12}{|c|}{ FIGO stage } \\
\hline$|-| \mid$ & $\begin{array}{l}154 \\
(87.5)\end{array}$ & $8632(6244)$ & 0.645 & $96.26(35.84)$ & 0.458 & $13.92(17.92)$ & 0.747 & $4.58(3.64)$ & 0.793 & $27.24(5.26)$ & 0.893 \\
\hline III-IV & $\begin{array}{l}22 \\
(12.5)\end{array}$ & 8754 (5768) & & $87.82(32.85)$ & & $14.12(20.24)$ & & $4.78(3.89)$ & & $27.92(4.92)$ & \\
\hline \multicolumn{12}{|c|}{ Lymphatic vascular space invasion } \\
\hline Yes & $\begin{array}{l}62 \\
(35.2)\end{array}$ & $8132(5948)$ & 0.821 & $91.21(36.14)$ & 0.452 & $16.82(24.87)$ & 0.604 & $4.73(3.68)$ & 0.894 & $27.42(5.61)$ & 0.793 \\
\hline No & $\begin{array}{l}114 \\
64.8)\end{array}$ & $8241(6005)$ & & $93.46(33.86)$ & & $14.93(22.64)$ & & $4.81(3.76)$ & & $27.29(5.11)$ & \\
\hline \multicolumn{12}{|c|}{ Myometrial invasion } \\
\hline $\begin{array}{l}< \\
50 \%\end{array}$ & $\begin{array}{l}79 \\
(44.9)\end{array}$ & $8642(6391)$ & 0.729 & $94.18(37.25)$ & 0.864 & $12.56(16.24)$ & 0.151 & $4.45(3.51)$ & 0.934 & $27.56(7.29)$ & 0.391 \\
\hline $\begin{array}{l}\geq \\
50 \%\end{array}$ & $\begin{array}{l}97 \\
(55.1)\end{array}$ & $8294(5943)$ & & $92.16(34.91)$ & & $14.95(24.62)$ & & $4.65(3.14)$ & & $26.98(4.73)$ & \\
\hline \multicolumn{12}{|c|}{ Histological grade } \\
\hline G1 & $\begin{array}{l}105 \\
59.7)\end{array}$ & 9134 (7424) & 0.693 & 91.16 (27.23) & 0.614 & $12.48(14.68)$ & 0.534 & $3.87(2.32)$ & 0.384 & $26.72(5.72)$ & 0.123 \\
\hline G2 & $\begin{array}{l}71 \\
(40.3)\end{array}$ & $9251(5842)$ & & 97.37 (37.51) & & $15.96(19.44)$ & & $4.62(3.64)$ & & $26.98(4.49)$ & \\
\hline
\end{tabular}

levels of VEGF-A were positively correlated with serum levels of Ang-2 and CRP $(r=0.18 ; p<0.001, r=0.25 ; p<$ 0.001 , respectively). The Ang-2 levels showed a positive correlation with CRP and C-peptide $(r=0.44 ; p<0.001$, $r=0.16 ; p=0.009$, respectively). The C-peptide levels showed a positive correlation with IGF-1, insulin and BMI $(r=0.16 ; p=0.01, r=0.66 ; p<0.001, r=0.24 ; p<0.001$, respectively). A positive correlation was observed between IGF-1 and insulin $(r=0.17 ; p=0.02)$ and insulin with BMI $(r=0.19 ; p<0.001)$. No significant correlation was found between any other serum level combinations of analyzed markers (Table 4).

Within 5 years of observation, 44 patients died of various causes present in the cohort. Kaplan-Meier survival analysis revealed that patients with high serum levels of CRP $(P=0.03)$ and Ang-2 $(P=0.015)$ had significantly worse outcomes (Fig. $1 \mathrm{a}$ and b). Cox regression analysis of individual predictors revealed that Ang-2, CRP, FIGO stage $(P<0.001$, respectively), LVSI $(P=0.009)$ and age $(P=0.013)$ appeared to be significant predictors of overall survival rate for the whole cohort. These predictors were then analyzed together in a multivariate analysis in which the predictive significance of Ang-2 $(P=0.006)$, CRP $(P=0.015)$, FIGO stage $(P<0.001)$ and age $(P=0.017)$ was confirmed (Table 5$)$.

\section{Discussion}

The prevalence of EC is alarmingly high due to the increasing number of older women in populations and frequent cases of obesity. In fact, the $5 \mathrm{~kg} / \mathrm{m} 2$ increase in BMI relates to a significant increase in EC [RR: 1.50 $(1.42-1.59)][24,25]$. Over $70 \%$ of women with type 1 $\mathrm{EC}$ are obese. For women with EC and BMI in the range $30-34.9$, the RR of mortality was 2.53 , and with BMI exceeding 40 the RR of mortality went up to 6.25 . Women with BMI over 40 are characterized by significantly shorter survival rates and suffer from more endometrial cancer unrelated deaths when compared with non-obese women [8, 25-28]. Earlier studies suggest that BMI is negatively correlated with EC survival rate, although this association is questionable $[29,30]$. In the current study, just like in the research by Mauland et al. [31] BMI had no independent prognostic impact on EC patients' 
Table 4 Pearson's correlation coefficient between angiogenic, inflammation and obesity-related factors in type 1 endometrial cancers patients

\begin{tabular}{|c|c|c|c|c|c|c|c|c|}
\hline & VEGF-A & Ang-2 & CRP & Adiponectin & IGF-1 & Insulin & C-peptide & BMI \\
\hline \multicolumn{9}{|l|}{ VEGF-A } \\
\hline CC & 1 & & & & & & & \\
\hline \multicolumn{9}{|l|}{ Significance } \\
\hline \multicolumn{9}{|l|}{ Ang-2 } \\
\hline $\mathrm{CC}$ & 0.18 & 1 & & & & & & \\
\hline Significance & $<0.001$ & & & & & & & \\
\hline \multicolumn{9}{|l|}{ CRP } \\
\hline $\mathrm{CC}$ & 0.25 & 0.44 & 1 & & & & & \\
\hline Significance & $<0.001$ & $<0.001$ & & & & & & \\
\hline \multicolumn{9}{|l|}{ Adiponectin } \\
\hline CC & 0.03 & 0.04 & -0.03 & 1 & & & & \\
\hline Significance & 0.521 & 0.299 & 0.748 & & & & & \\
\hline \multicolumn{9}{|l|}{ IGF-1 } \\
\hline $\mathrm{CC}$ & 0.12 & -0.02 & -0.17 & -0.19 & 1 & & & \\
\hline Significance & 0.071 & 0.834 & $<0.001$ & $<0.001$ & & & & \\
\hline \multicolumn{9}{|l|}{ Insulin } \\
\hline CC & 0.04 & 0.03 & -0.07 & -0.17 & 0.17 & 1 & & \\
\hline Significance & 0.548 & 0.692 & 0.163 & 0.003 & 0.02 & & & \\
\hline \multicolumn{9}{|l|}{ C-peptide } \\
\hline CC & 0.03 & 0.16 & -0.02 & -0.16 & 0.16 & 0.66 & 1 & \\
\hline Significance & 0.782 & 0.009 & 0.701 & 0.02 & 0.01 & $<0.001$ & & \\
\hline \multicolumn{9}{|l|}{ BMI } \\
\hline CC & 0.03 & -0.02 & 0.06 & -0.31 & 0.08 & 0.19 & 0.24 & 1 \\
\hline Significance & 0.421 & 0.538 & 0.292 & $<0.001$ & 0.116 & $<0.001$ & $<0.001$ & \\
\hline
\end{tabular}

CC correlation coefficient

survival despite the fact that $90.4 \%$ of women with type 1 EC were overweight or obese. Our data demonstrate that women with type $1 \mathrm{EC}$ enrolled in our study had their BMI associated with age and not with other clinicopathological factors.

Obesity contributes to the progression of metabolic syndrome, which can be identified by insulin resistance, which in turn is a risk factor for EC [25, 32, 33]. Chronic hyperinsulinemia causes the secretion of IGF-1 and lowers the production of IGF binding proteins, which consecutively heightens circulating levels of IGF. IGF-1 binding to the cognate receptor, IGF-1R, triggers a signaling cascade leading to proliferative and anti-apoptotic events $[25,34]$. In our study pretreatment levels of adiponectin, IGF-1, C-peptide and insulin in blood did not correlate with clinicopathological variables and with patients' cumulative survival. Similar results were obtained by Volkova et al. [35] in patients with colorectal cancer. Nevertheless, the individual contributions of these factors to obesity-related tumors, including type $1 \mathrm{EC}$, are not fully understood. However, it does not seem that any of the markers assessed here can be effectively used to define EC type 1.

Obesity changes profiles of cytokines and thus influences the chronic inflammatory conditions. Adipose tissue secretes leptin, VEGF, IL-1, IL-6, hepatocyte growth factor (HGF) and TNF- $\alpha$ that could induce tumor neoangiogenesis leading to the progression of solid tumors [25, 36]. Increased levels of angiogenic markers could be connected to poor outcomes and high grades in type $1 \mathrm{EC}[25,37]$. In our previous study we have proved that preoperative serum VEGF levels could be a beneficial marker to foresee 5-year illness-free survival in type $2 \mathrm{EC}$ [38].

It is a well-known fact that levels of Ang-2 are elevated in serum of adult patients with metabolic syndrome [39], as well as in some obese adults [40, 41], where Ang-2 is evidently correlated with vascular disorders [42]. A meta-analysis carried out by $\mathrm{Xu}$ et al. [21] showed that elevated levels of Ang-2 in lung cancer are associated with poor prognosis. Although the absolute participation of Ang-2 in cancer development is not 


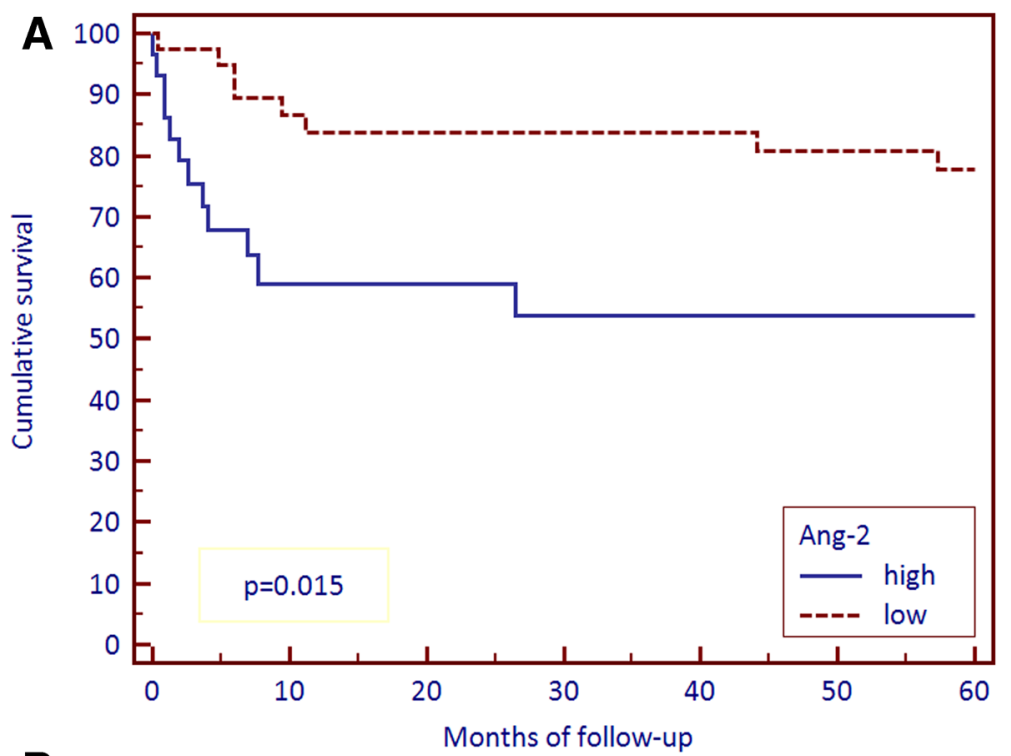

B

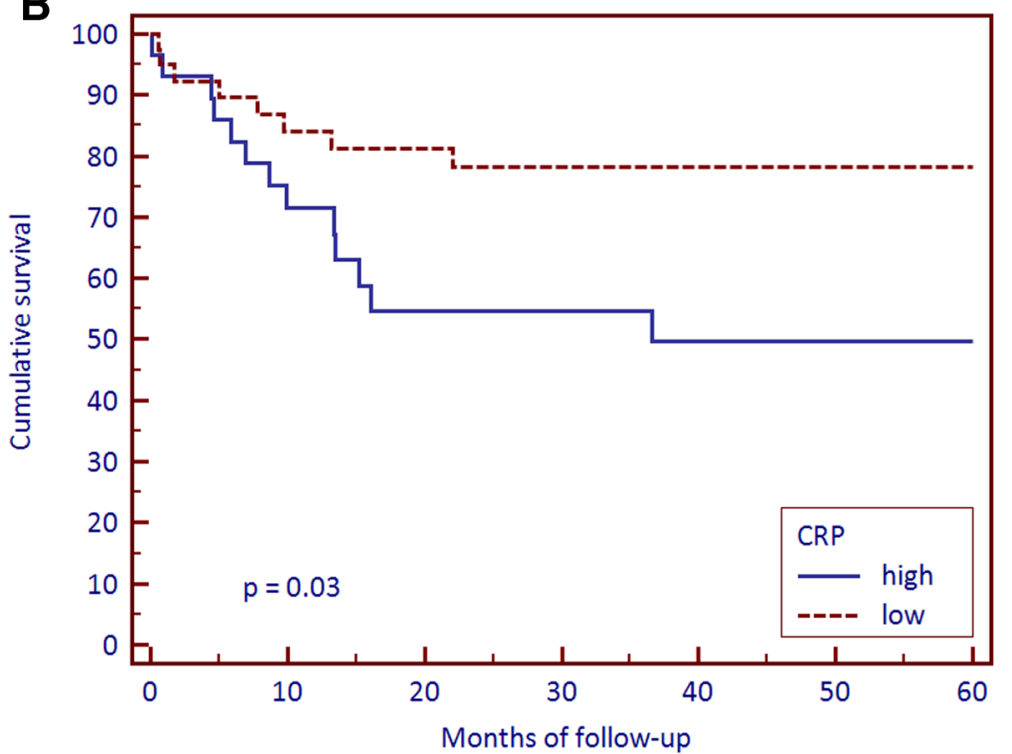

Fig. 1 Survival of endometrioid endometrial cancer patients from surgery to death from any cause by Kaplan-Meier survival analysis. Survival between groups with high and low serum $\mathbf{a}$ Ang-2 and $\mathbf{b}$ CRP. Median values were used as cut-points for high vs low values

evident so far, it is possible that higher levels of Ang-2, together with elevated levels of VEGF-A, have an additional effect on neoangiogenesis, as well as on the instability of new blood vessels [43]. Cullberg et al. [44] observed decrease of VEGF and Ang-2 levels in blood serum during weight loss that indicates their generally reduced angiogenic activity. In addition, these results indicate that VEGF-A and Ang-2 are associated with obesity and possibly with the development of other obesity-related diseases such as endometrial cancer. Volkova et al. [35] claim that serum Ang-2 levels were a stronger predictor of survival than serum VEGF-A levels, which are the main angiogenic factor associated with poor colorectal cancer outcomes [45]. In our study we found that in EC type 1 patients, serum levels of Ang-2 increased with the depth of myometrial infiltration, LVSI, and age. Especially patients in stage III-IV (FIGO) had the highest levels of Ang-2, which can suggest the key role of Ang-2 in the development of tumor and metastases. Moreover, much higher serum Ang-2 levels in patients with LVSI might also reveal the fact that Ang-2 is a potential biomarker that can be used in the evaluation of staging. Although some evidence suggests that the expression of Ang-2 in tumor tissue indicates poor prognosis, only a few studies evaluated the levels of Ang-2 in circulation [46-50]. However, so far there has 
Table 5 Cox regression survival analyses

\begin{tabular}{|c|c|c|c|}
\hline & Hazard ratio & $95 \% \mathrm{Cl}$ for $\mathrm{HR}$ & Total $P$-value \\
\hline \multicolumn{4}{|l|}{ Univariate analysis } \\
\hline \multicolumn{4}{|l|}{ Base model } \\
\hline \multicolumn{4}{|l|}{ FIGO stage } \\
\hline III-IV vs I-II & 5.98 & $3.11-9.89$ & $<0.001$ \\
\hline \multicolumn{4}{|l|}{ Age (years) } \\
\hline$>60$ vs $\leq 60$ & 2.31 & $1.24-4.58$ & 0.013 \\
\hline \multicolumn{4}{|l|}{ Grade } \\
\hline 1 vs 2 & 2.59 & $1.16-4.86$ & 0.062 \\
\hline \multicolumn{4}{|c|}{ Myometrial invasion } \\
\hline$>50 \%$ vs $\leq 50 \%$ & 3.28 & $1.83-5.92$ & $<0.001$ \\
\hline \multicolumn{4}{|l|}{ LVSI } \\
\hline yes vs no & 2.63 & $1.24-4.76$ & 0.009 \\
\hline \multicolumn{4}{|c|}{ Additions to model ${ }^{a}$} \\
\hline VEGF-A & 1.02 & $0.25-3.64$ & 0.74 \\
\hline Ang-2 & 1.29 & $1.09-1.59$ & $<0.001$ \\
\hline Adiponectin & 1.01 & $0.99-1.06$ & 0.923 \\
\hline Insulin & 1.00 & $0.98-1.02$ & 0.914 \\
\hline C-peptide & 1.02 & $0.97-1.06$ & 0.689 \\
\hline CRP & 1.37 & $1.03-1.61$ & $<0.001$ \\
\hline IGF-1 & 1.01 & $0.96-1.05$ & 0.893 \\
\hline BMl & 0.84 & $0.45-1.41$ & 0.472 \\
\hline \multicolumn{4}{|c|}{ Multivariate analysis } \\
\hline \multicolumn{4}{|l|}{ Base model } \\
\hline \multicolumn{4}{|l|}{ FIGO stage } \\
\hline III-IV vs I-II & 3.57 & $1.79-6.94$ & $<0.001$ \\
\hline \multicolumn{4}{|l|}{ Age (years) } \\
\hline$>60$ vs $\leq 60$ & 2.21 & $1.19-4.32$ & 0.017 \\
\hline \multicolumn{4}{|l|}{ Grade } \\
\hline 1 vs 2 & 1.52 & $1.18-2.96$ & 0.683 \\
\hline \multicolumn{4}{|c|}{ Myometrial invasion } \\
\hline$>50 \%$ vs $\leq 50 \%$ & 1.11 & $0.49-2.09$ & 0.861 \\
\hline \multicolumn{4}{|l|}{ LVSI } \\
\hline yes vs no & 1.16 & $0.53-2.36$ & 0.734 \\
\hline \multicolumn{4}{|l|}{ Additions to model $^{b}$} \\
\hline Ang-2 & 1.31 & $1.02-1.69$ & 0.006 \\
\hline CRP & 1.22 & $1.01-1.43$ & 0.015 \\
\hline
\end{tabular}

${ }^{\text {a }}$ The base model consisted of traditional prognostic factors, and we separately entered the parameters in a second block

${ }^{\mathrm{b}}$ Additions to the used model (all continuous, log-transformed, and separately entered)

been no uniform conclusion. According to our current data, the level of serum Ang-2 might be a key prognostic factor in type $1 \mathrm{EC}$. Our results suggest better prognosis in patients with lower serum Ang-2 levels before treatment.
Excess adipose tissue is associated with elevated levels of the pro-inflammatory CRP marker in the bloodstream. Elevated levels of CRP and its IL-6 inducer might also serve as a predictive factor of the development of type 1 EC [11]. In a large population-based case-control study, a statistically significant 1.25 higher risk of EC type I development per unit of CRP growth was observed. Not many clinical trials so far have investigated the relationship between inflammatory markers and the risk of EC development. Research from the European Investigation into Cancer cohort indicates statistically significant increased risks of EC for elevated levels of prediagnostic, prospectively controlled CRP levels $(\mathrm{OR}=1.58,95 \% \mathrm{CI}: 1.03-2.41)[5,11]$. In the clinical study described by Gathirua-Mwangi et al. [51] focused on 10,014 women aged 18 years and older who participated in NHANES III (Third National Health and Nutrition Examination Survey) a total of 400 cases of cancer deaths were documented, with 140 cases of deaths from obesity-related cancers (breast, colorectal, pancreatic and endometrial). Cox proportional hazards regression was used to estimate multivariable-adjusted hazard ratios (HR) for cancer mortality. Metabolic syndrome and CRP were associated with increased total cancer mortality $[\mathrm{HR}=1.33,95 \%$ CI $1.04-1.70]$. In our study, this value was $\mathrm{HR}=1.37,95 \% \mathrm{CI}$ : $1.03-1.61$ for CRP, respectively. Our results correspond to previous reports on CRP in EC, where elevated serum CRP levels were associated with more aggressive tumor behavior, higher tumor development stages, and poor prognosis. Multivariable analysis showed that CRP is an independent prognostic factor in patients with type $1 \mathrm{EC}$ with significantly worse overall prognosis. Higher preoperative levels of CRP were related to increased mortality. Measurements of CRP in type 1 EC could be easily integrated into routine diagnostic procedures. However, it is known that CRP is not a specific tumor marker for EC, therefore exclusion of other reasons for increased serum CRP before suspecting EC is crucial. Only then, the information on CRP serum concentrations in type $1 \mathrm{EC}$ could be evaluated in relation to tumor stage or prognosis and could be used to support decisions about adjuvant chemotherapy.

\section{Conclusions}

In conclusion, our research has shown that obesityrelated angiogenesis and inflammation are related to the development of type $1 \mathrm{EC}$ and survival. In our study, a significant correlation was found between serum Ang-2 and CRP levels and outcome of the patients with type 1 EC. The obtained results suggest that the levels of Ang-2 and CRP in the blood could be used as prognostic factors both, in diagnosis and in the treatment of type 1 EC. Moreover, the correlation between these proteins 
and type $1 \mathrm{EC}$ suggests that it might potentially serve as a marker helping to predict the prognosis and to offer the possibility of customizing the treatment regimen. It is believed that the combined measurement of currently used tumor markers will improve sensitivity and specificity for type $1 \mathrm{EC}$ management. However, the values of longitudinal measurements of the used markers before and after therapy have not yet been determined.

\section{Abbreviations}

type 1 EC: Endometrioid endometrial cancer; CRP: C-reactive protein; VEGFA: Vascular endothelial growth factor-A; Ang-2: Angiopoietin-2; IGF-1: Insulinlike growth factor-1; LVSI: Lymphatic vascular space invasion; FIGO: International Federation of Gynecology and Obstetrics; TNF-a: Tumor necrosis factor a; IL-6: Interleukin-6; IGFBP2: Insulin like growth factor binding protein 2; SHBG: Sex hormone binding globulin; HGF: Hepatocyte growth factor; NHANES III: Third National Health and Nutrition Examination Survey

\section{Acknowledgements}

Not Applicable.

\section{Authors' contributions}

KMT study design, data collection, data generation, data analysis, data interpretation, manuscript writing; BD study design, data interpretation, manuscript writing; RT data generation, data analysis, manuscript writing; AS data generation, data analysis, manuscript writing; MK data collection, manuscript writing; SJT study design, data analysis, data interpretation, manuscript writing. All authors read and approved the final manuscript.

\section{Funding}

The research was financed from the statutory subsidy obtained by the Faculty of Health Sciences of the Medical University of Bialystok. The funders had no role in study design, data collection and analysis, decision to publish, or preparation of the manuscript.

\section{Availability of data and materials}

The datasets generated during and/or analysed during the current study are not publicly available as study participants were assured raw data would remain confidential and not be shared.

\section{Ethics approval and consent to participate}

This study was approved by the Bioethics Committee at the Medical University of Bialystok, Poland (R-I-003/177/2004). Patients signed their Informed consent forms before the study.

\section{Consent for publication}

Not Applicable.

\section{Competing interests}

The authors have stated explicitly that there are no conflicts of interest in connection with this article.

\footnotetext{
Author details

${ }^{1}$ Department of Food Biotechnology, Medical University of Bialystok, Szpitalna 37 Street, 15-295 Bialystok, Poland. ${ }^{2}$ Department of Gynecology and Obstetrics, Medical University of Bialystok, M. Sklodowskiej-Curie 24A Street, 15-089 Bialystok, Poland. ${ }^{3}$ Department of Rehabilitation, Medical University of Bialystok, M. Sklodowskiej-Curie 24A Street, 15-089 Bialystok, Poland. ${ }^{4}$ Department of Gynecology and Obstetrics of the Independent Public Healthcare Facility Regional Complex Jan Sniadecki Hospital, M. Sklodowskiej-Curie 26 Street, 15-950 Bialystok, Poland. ${ }^{5}$ Department of Obstetrics, Gynaecology and Maternity Care, Medical University of Bialystok, Szpitalna 37 Street, 15-295 Bialystok, Poland.
}

Received: 17 September 2019 Accepted: 15 September 2020 Published online: 25 September 2020

\section{References}

1. Bray F, Ferlay J, Soerjomataram I, Siegel RL, Torre LA, Jemal A. Global cancer statistics 2018: GLOBOCAN estimates of incidence and mortality worldwide for 36 cancers in 185 countries. CA Cancer J Clin. 2018:68(6):394-424.

2. Reports based on data of National Cancer Registry. The Maria SklodowskaCurie Memorial Cancer Center. Department of Epidemiology and Cancer Prevention, National Cancer Registry. http://onkologia.org.pl/k/baza-on-line/. Accessed 23 Oct 2018

3. Morice P, Leary A, Creutzberg C, Abu-Rustum N, Darai E. Endometrial cancer Lancet. 2016:387(10023):1094-108.

4. Murali R, Soslow RA, Weigelt B. Classification of endometrial carcinoma: more than two types. Lancet Oncol. 2014;15(7):e268-78. https://doi.org/10. 1016/S1470-2045(13)70591-6.

5. Dossus L, Rinaldi S, Becker S, Lukanova A, Tjonneland A, Olsen A, et al. Obesity, inflammatory markers, and endometrial cancer risk: a prospective case-control study. Endocr Relat Cancer. 2010;17(4):1007-19.

6. Moore K, Brewer MA. Endometrial Cancer: is this a new disease? Am Soc Clin Oncol Educ Book. 2017;37:435-42.

7. Dobrzycka B, Terlikowski SJ. Biomarkers as prognostic factors in endometrial cancer. Folia Histochem Cytobiol. 2010;48(3):319-22.

8. Shaw E, Farris M, McNeil J, Friedenreich C. Obesity and endometrial Cancer. Recent Results Cancer Res. 2016;208:107-36.

9. Linkov F, Goughnour SL, Ma T, Xu Z, Edwards RP, Lokshin AE, et al. Changes in inflammatory endometrial cancer risk biomarkers in individuals undergoing surgical weight loss. Gynecol Oncol. 2017;147(1):133-8.

10. Wang T, Rohan TE, Gunter MJ, Xue X, Wactawski-Wende J, Rajpathak SN, et al. A prospective study of inflammation markers and endometrial cancer risk in postmenopausal hormone nonusers. Cancer Epidemiol Biomark Prev. 2011:20(5):971-7.

11. Friedenreich CM, Langley AR, Speidel TP, Lau DC, Courneya KS, Csizmadi I, et al. Case-control study of inflammatory markers and the risk of endometrial cancer. Eur J Cancer Prev. 2013;22(4):374-9.

12. Busch EL, Crous-Bou M, Prescott J, Downing MJ, Rosner BA, Mutter GL, et al. Adiponectin, Leptin, and insulin-pathway receptors as endometrial Cancer subtyping markers. Horm Cancer. 2018;9(1):33-9.

13. Nimptsch K, Pischon T. Obesity biomarkers, metabolism and risk of Cancer: an epidemiological perspective. Recent Results Cancer Res. 2016;208:199217.

14. Liao C, Zhang D, Mungo C, Tompkins DA, Zeidan AM. Is diabetes mellitus associated with increased incidence and disease-specific mortality in endometrial cancer? A systematic review and meta-analysis of cohort studies. Gynecol Oncol. 2014;135(1):163-71.

15. Zhang Y, Liu H, Yang S, Zhang J, Qian L, Chen X. Overweight, obesity and endometrial cancer risk: results from a systematic review and meta-analysis. Int J Biol Markers. 2014;29(1):e21-9. https://doi.org/10.5301/jbm.5000047.

16. Zhang $Z H$, Su PY, Hao JH, Sun YH. The role of preexisting diabetes mellitus on incidence and mortality of endometrial cancer: a meta-analysis of prospective cohort studies. Int J Gynecol Cancer. 2013;23(2):294-303.

17. Saito M, Sato Y, Watanabe J, Kuramoto H, Kaba S, Fukuda T. Angiogenic factors in normal endometrium and endometrial adenocarcinoma. Pathol Int. 2007:57(3):140-7.

18. Scholz A, Plate KH, Reiss Y. Angiopoietin-2: a multifaceted cytokine that functions in both angiogenesis and inflammation. Ann N Y Acad Sci. 2015: 1347:45-51.

19. Dong Z, Chen J, Yang X, Zheng W, Wang L, Fang M, et al. Ang-2 promotes lung cancer metastasis by increasing epithelial-mesenchymal transition. Oncotarget. 2018:9(16):12705-17.

20. Semenza GL. Cancer-stromal cell interactions mediated by hypoxiainducible factors promote angiogenesis, lymphangiogenesis, and metastasis. Oncogene. 2013;32:4057-63.

21. Xu Y, Zhang $Y$, Wang Z, Chen N, Zhou J, Liu L. The role of serum angiopoietin-2 levels in progression and prognosis of lung cancer: a metaanalysis. Medicine (Baltimore). 2017;96(37):e8063. https://doi.org/10.1097/ MD.0000000000008063.

22. Garrett $P E$, Lasky FD, Meier KL. User protocol for evaluation of qualitative test performance: Approved guideline-Second edition. CLSI EP121-A2 2008. http://www.clsi.org. Accessed 11 Dec 2018. 
23. WHO. Body mass index-BMI. https://www.euro.who.int/en/health-topics/ disease-prevention/nutrition/a-healthy-lifestyle/body-mass-index-bmi. Accessed 17 Sept 2020.

24. World Cancer Research Fund International. http://www.wcrf.org/int/cancerfacts-figures/link-between-lifestyle-cancer-risk/cancers-linked-greater-bodyfatness. Accessed 23 Oct 2018.

25. Daley-Brown D, Oprea-llies GM, Lee R, Pattillo R, Gonzalez-Perez RR. Molecular cues on obesity signals, tumor markers and endometrial cancer. Horm Mol Biol Clin Invest. 2015;21(1):89-106.

26. Onstad MA, Schmandt RE, Lu KH. Addressing the role of obesity in endometrial Cancer risk, prevention, and treatment. J Clin Oncol. 2016; 34(35):4225-30.

27. Sorosky Jl. Endometrial cancer. Obstet Gynecol. 2012;120(2 Pt 1):383-97.

28. Arem $\mathrm{H}$, Irwin ML. Obesity and endometrial cancer survival: a systematic review. Int J Obes. 2013;37(5):634-9.

29. McTiernan A, Irwin M, Vongruenigen V. Weight, physical activity, diet, and prognosis in breast and gynecologic cancers. J Clin Oncol. 2010;28(26): 4074-80.

30. Fader AN, Arriba LN, Frasure HE, von Gruenigen VE. Endometrial cancer and obesity: epidemiology, biomarkers, prevention and survivorship. Gynecol Oncol. 2009;114(1):121-7.

31. Mauland KK, Trovik J, Wik E, Raeder MB, Njolstad TS, Stefansson IM, et al. High BMl is significantly associated with positive progesterone receptor status and clinico-pathological markers for non-aggressive disease in endometrial cancer. Br J Cancer. 2011;104(6):921-6.

32. Papatla K, Huang M, Slomovitz B. The obese endometrial cancer patient: how do we effectively improve morbidity and mortality in this patient population? Ann Oncol. 2016;27(11):1988-94.

33. Nevadunsky NS, Van Arsdale A, Strickler HD, Moadel A, Kaur G, Levitt J, et al Obesity and age at diagnosis of endometrial cancer. Obstet Gynecol. 2014; 124(2 Pt 1):300-6.

34. Bruchim I, Sarfstein R, Werner H. The IGF Hormonal Network in Endometrial Cancer: Functions, Regulation, and Targeting Approaches. Front Endocrinol (Lausanne). 2014;5:76. https://doi.org/10.3389/fendo.2014.00076.

35. Volkova E, Willis JA, Wells JE, Robinson BA, Dachs GU, Currie MJ. Association of angiopoietin-2, C-reactive protein and markers of obesity and insulin resistance with survival outcome in colorectal cancer. Br J Cancer. 2011; 104(1):51-9.

36. Borghi C, Indraccolo U, Scutiero G, lannone P, Martinello R, Greco P, et al. Biomolecular basis related to inflammation in the pathogenesis of endometrial cancer. Eur Rev Med Pharmacol Sci. 2018;22(19):6294-9.

37. Dobrzycka B, Terlikowski SJ, Kwiatkowski M, Garbowicz M, Kinalski M, Chyczewski L. Prognostic significance of VEGF and its receptors in endometrioid endometrial cancer. Ginekol Pol. 2010;81:422-5.

38. Dobrzycka B, Mackowiak-Matejczyk B, Kinalski M, Terlikowski SJ. Pretreatment serum levels of bFGF and VEGF and its clinical significance in endometrial carcinoma. Gynecol Oncol. 2013;128(3):454-60.

39. Lorbeer R, Baumeister SE, Dörr M, Nauck M, Grotevendt A, Schlesinger S, et al. Angiopoietin-2, its soluble receptor Tie-2, and metabolic syndrome components in a population-based sample. Obesity (Silver Spring). 2016; 24(10):2038-41.

40. Silha JV, Krsek M, Sucharda P, Murphy LJ. Angiogenic factors are elevated in overweight and obese individuals. Int J Obes. 2005:29(11):1308-14.

41. Kaess BM, Pedley A, Massaro JM, Larson MG, Corsini E, Hoffmann U, et al. Relation of vascular growth factors with CT-derived measures of body fat distribution: the Framingham heart study. J Clin Endocrinol Metab. 2012; 97(3):987-94.

42. David S, Kümpers P, Lukasz A, Kielstein JT, Haller H, Fliser D. Circulating angiopoietin-2 in essential hypertension: relation to atherosclerosis, vascular inflammation, and treatment with olmesartan/pravastatin. J Hypertens. 2009; 27(8):1641-7.

43. Wang Q, Lash GE. Angiopoietin 2 in placentation and tumor biology: the yin and yang of vascular biology. Placenta. 2017;56:73-8.

44. Cullberg KB, Christiansen T, Paulsen SK, Bruun JM, Pedersen SB, Richelsen B. Effect of weight loss and exercise on angiogenic factors in the circulation and in adipose tissue in obese subjects. Obesity (Silver Spring). 2013;21(3): 454-60

45. Cao D, Hou M, Guan YS, Jiang M, Yang Y, Gou HF. Expression of HIF-1alpha and VEGF in colorectal cancer: association with clinical outcomes and prognostic implications. BMC Cancer. 2009;9:432. https://doi.org/10.1186/ 1471-2407-9-432.
46. Coelho AL, Gomes MP, Catarino RJ, Rolfo C, Medeiros RM, Araújo AM. CSF-1 and Ang-2 serum levels - prognostic and diagnostic partners in non-small cell lung cancer. ESMO Open. 2018;3(5):e000349. https://doi.org/10.1136/ esmoopen-2018-000349.

47. Barron GA, Goua M, Wahle KWJ, Bermano G. Circulating levels of angiogenesis-related growth factors in breast cancer: a study to profile proteins responsible for tubule formation. Oncol Rep. 2017;38(3):1886-94.

48. Yang $\mathrm{P}$, Chen $\mathrm{N}$, Yang D, Crane J, Yang S, Wang $\mathrm{H}$, et al. The ratio of serum Angiopoietin-1 to Angiopoietin-2 in patients with cervical cancer is a valuable diagnostic and prognostic biomarker. PeerJ. 2017;5:e3387. https:// doi.org/10.7717/peerj.3387.

49. Atesoglu EB, Tarkun P, Mehtap O, Demirsoy ET, Atalay F, Maden M, et al. Serum Angiopoietin levels are different in acute and chronic myeloid neoplasms: Angiopoietins do not only regulate tumor angiogenesis. Indian J Hematol Blood Transfus. 2016;32(2):162-7.

50. Wang ZQ, Sun XL, Su HL, Liu XF, Xuan YJ, Yu SQ. Association between serum angiopoietin-2 concentration and clinicopathological parameters in patients with colorectal cancer. Genet Mol Res. 2015;14(4):15547-52.

51. Gathirua-Mwangi WG, Song Y, Monahan PO, Champion VL, Zollinger TW. Associations of metabolic syndrome and C-reactive protein with mortality from total cancer, obesity-linked cancers and breast cancer among women in NHANES III. Int J Cancer. 2018;143(3):535-42.

\section{Publisher's Note}

Springer Nature remains neutral with regard to jurisdictional claims in published maps and institutional affiliations.
Ready to submit your research? Choose BMC and benefit from:

- fast, convenient online submission

- thorough peer review by experienced researchers in your field

- rapid publication on acceptance

- support for research data, including large and complex data types

- gold Open Access which fosters wider collaboration and increased citations

- maximum visibility for your research: over $100 \mathrm{M}$ website views per year

At BMC, research is always in progress.

Learn more biomedcentral.com/submissions 